\title{
Biological Activity of Tannins from Acacia mangium Bark Extracted by Different Solvents
}

\author{
E. Wina*, Susana I.W.R., \& B. Tangendjaja \\ Indonesian Research Institute for Animal Production (Balitnak) \\ P.O. Box 221 Bogor 16002 Indonesia \\ (Received 19-03-2010; accepted 02-07-2010)
}

\begin{abstract}
Acacia mangium bark is abundant byproduct of wood industry in Indonesia. It is underutilized and mainly used as fire wood for the wood industry. The bark contains high level of tannin but the tannin has not been extracted or produced commercially. Tannin isolate can be used for several purposes such as tanning agent for leather, adhesive for plywood or particle board, etc. In ruminant, tannin can be detrimental but can also be beneficial. This experiment was aimed of getting the highest yield of tannin extract with the highest biological activity in rumen fermentation. Nine different solvents at different temperatures were used to extract tannin from A. mangium bark. The extracts were analyzed for their tannin contents and biological activities. Tannin content was analyzed using folin ciocalteau and butanol-HCl methods. Biological activity was described as a percentage of an increase in gas production in the in vitro rumen-buffer fermentation, with and without addition of PEG. The results show that $\mathrm{Na}_{2} \mathrm{SO}_{3}$ solution extracted more tannin than other solutions and the higher the concentration of $\mathrm{Na}_{2} \mathrm{SO}_{3}$ solution, the higher the yield of tannin extract. The solution of $6 \%$ sodium sulphite gave the highest yield of tannin extract ( $31.2 \%$ of original bark sample) and the highest concentration of tannin (18.26\%) but produced a negative effect on in vitro fermentation (\% increase of gas production $=\mathbf{2 . 7 0} \%)$. Extraction with $50 \%$ acetone gave a high yield of extract $(22.28 \%$ of original bark) which contained $12.98 \%$ of tannin and showed the highest biological response (\% increase of gas production $=\mathbf{2 1 6} \%$ ). In conclusion, sodium sulphite solution is not recommended for tannin extraction if the tannin will be used as feed additive in ruminant feed; on the other hand, the aqueous acetone ( $50 \%$ acetone) solution is a better choice to be used.
\end{abstract}

Key words: tannin, Acacia mangium bark, extraction, biological activity

\section{INTRODUCTION}

Tannin can be found in many different parts of the plant due to its function as plant protection against predator. Several commercial tannins, however, were extracted mainly from the bark. Those barks were Acacia mearsnii (Duan et al., 2005), quebracho, Pinus radiata (Li \& Maplesden, 1998), Eucalyptus camadulensis (Ofinade, 1997), Western hemlock (Herrick, 1980), chestnut (Castanea vesca) (Krisper et al., 1992)

Tannins are utilized for several purposes. After mimosa and quebracho tannin, tannin from chestnut is the third most important vegetable tannin used for leather production in Northern side of Mediterranean Sea (Krisper et al., 1992). Pinus radiata bark tannins were used as adhesives (Li \& Maplesden, 1998) or chemically

\footnotetext{
*Corresponding author:

Indonesian Research Institute for Animal Production (Balitnak)

P.O. Box 221 Bogor 16002 Indonesia

Phone: 62-251-8240752, fax:62-251-8240754

e-mail: winabudi@yahoo.com
}

modified with an acidified formaldehyde solution and used for removing metal ions from aqueous solutions and copper mine acidic residual waters (Palma et al., 2003). Tannin extracted from Western hemlock bark has been used for lowering fluid viscosity of the drilling fluid, as the intermediates for phenolic resin for plywood industry and as the carriers for micronutrient elements that are required for plant growth (Herrick, 1980). In the animal nutrition aspect, the presence of tannin in the animal feed can be detrimental or beneficial. High level of tannin reduces protein digestibility, mineral availability and reduces digestive enzymes. However, the beneficial effect of tannin has also been reported by several authors. A castalagin-based pharmaceutical product from chesnut bark is currently in use for prevention and treatment of diarrhea in pigs and cattle that is caused by changes in diet (Krisper et al., 1992). A tannin containing diet successfully reduced the number of worm in the digestive tract of sheep or goat (Cenci et al., 2007). A protein-tannin complex could increase the supply of amino acid to the animal, hence improved growth (Min et al., 2003). 
There are several methods to extract tannin from bark have been reported (Herrick, 1980; Susana et al., 1994; Ofinade, 1997; Li \& Maplesden, 1998; Duan et al., 2005; Yano, personal communication). Tannins were extracted by water or aqueous solvent and have been used mostly for industrial purposes and very limited for animal feed.

Acacia mangium bark is abundant byproduct of wood industry in Indonesia. It is underutilized and mainly used as fire wood for the wood industry. The bark contains high level of tannin but the tannin has not been extracted or produced commercially. Therefore, the aim of this experiment was to obtain the best method for tannin extraction from Acacia mangium bark that gives the highest biological property of tannin in the rumen fermentation.

\section{MATERIALS AND METHODS}

\section{Materials}

Fresh barks of Acacia mangium were collected from Rumpin village, West Java. The fresh bark was cut into $15 \times 15 \mathrm{~cm}$ sizes and was air dried under the shade until dry. Then, the bark was milled and used as the tannin source.

\section{Methods}

To extract tannin from acacia bark, several published methods were used and compared (Herrick, 1980; Susana et al., 1994; Ofinade, 1997; Li \& Maplesden, 1998; Duan et al., 2005, Yano, personal communication).

Extraction of tannin. Five grams of dried milled acacia bark was extracted with $100 \mathrm{ml}$ of different solution or solvent and at different methods of extraction (Table 1). Each extraction was done in four replicates. Two extractive fractions were collected and dried in the oven at $105^{\circ} \mathrm{C}$ for 24 hours and the dry weight of the extractives was weighed and recorded. The data presented in this paper were the average of two replicates.

The other two fractions were used for further analyses (chemical and in vitro fermentation test). The tannin extract for the in vitro fermentation test was evaporated until the solution became almost dry. Then, it was redissolved in the buffer solution used in the in vitro fermentation.

Total phenol content was determined from the extractives fractions using Folin Ciocalteu method. Total tannin content in the different extracts was determined using modified Folin Ciocalteu method. Firstly, the analysis of the extract using Folin Ciocalteu was conducted to obtain total phenol content and then, polyvinylpyrolidone (PVP) was added to the supernatant. This supernatant was reacted with Folin Ciocalteu reagent to measure the non tannin phenolic content. The difference between total phenol and non tannin phenolic contents will be the total tannin content of the extract. Condensed tannin content was determined according to butanol- $\mathrm{HCl}$ method. Biological property of tannin was analysed using in vitro rumen fermentation where tan-
Table 1. Solution and method of extraction

\begin{tabular}{ll}
\hline \multicolumn{1}{c}{ Solution } & \multicolumn{1}{c}{ Method of extraction } \\
\hline Water & $\begin{array}{l}\text { Kept at room temperature for } \\
24 \text { hours }\end{array}$ \\
Water & $\begin{array}{l}\text { Kept in water-bath at } 100{ }^{\circ} \mathrm{C} \text { for } \\
40 \text { minutes }\end{array}$ \\
Water & Autoclave for 40 minutes \\
$0,04 \% \mathrm{NaOH}$ solution & $\begin{array}{l}\text { Kept in water-bath at } 100{ }^{\circ} \mathrm{C} \text { for } \\
40 \text { minutes }\end{array}$ \\
$2 \% \mathrm{Na}_{2} \mathrm{SO}_{3}$ solution & Autoclave for 40 minutes \\
$4 \% \mathrm{Na}_{2} \mathrm{SO}_{3}$ solution & Autoclave for 40 minutes \\
$6 \% \mathrm{Na}_{2} \mathrm{SO}_{3}$ solution & Autoclave for 40 minutes \\
$50 \% \mathrm{methanol}$ & Kept at room temperature for \\
$50 \%$ methanol $_{50}$ & 24 hours \\
$50 \%$ acetone & Reflux for 4 hours \\
& Reflux for 4 hours \\
$50 \%$ acetone & Kept at room temperature for \\
$50 \%$ acetone $+\mathrm{Na}_{2} \mathrm{SO}_{3} 2 \%$ & 24 hours \\
\hline
\end{tabular}

nin extract was added with and without polyethylene glycol (Makkar, 2003).

Measurement of tannin biological activity (tannin bioassay). The rumen liquor was obtained from fistulated sheep fed a mixture of elephant grass and concentrate. Then the rumen liquor was mixed with buffer solution and flushed with $\mathrm{CO}_{2}$ gas until reaching neutral $\mathrm{pH}$. Four hundred milligrams of soybean meal with and without $300 \mathrm{mg}$ of polyethylene glycol (PEG) were weighed into a glass bottle $(100 \mathrm{ml})$. Two millilitres of tannin solution extracted by different solutions and $38 \mathrm{ml}$ rumen liquor-buffer solution were added to the glass bottle and prepared in duplicates for each tannin extract. The bottles were incubated in the water bath at $39^{\circ} \mathrm{C}$ for 24 hours. The gas pressure was measured at 3 , $6,9,12$ and 24 hours of incubation. The volume of gas production was calculated based on the gas pressure. The biological activity is expressed as the percentage of an increase in total gas production with and without Polyethylene glycol addition.

Increase of gas production $(\%)=$

$(\mathrm{X}$ - blank $)$ - (Y - blank $) \times 100 \%$ (X - blank)

$X=$ average volume of gas with $P E G$

$\mathrm{Y}=$ average volume of gas without PEG

\section{RESULTS AND DISCUSSION}

\section{Yield of Tannin}

The yield of tannin was the lowest $(6.96 \%)$ when water was used for tannin extraction at room temperature (Table 2). This was in agreement with the report of Onifade (1997) who found that tannin yield from Eucalyptus camadulensis extracted with either tap water 
Table 2. The yield of tannin extracted by different solution and methods from Acacia mangium bark

\begin{tabular}{llc}
\hline \multicolumn{1}{c}{ Solution } & \multicolumn{1}{c}{ Method of extraction } & $\begin{array}{c}\text { Yield } \\
(\% \text { bark weight })\end{array}$ \\
\hline Water & Kept at room temperature for $24 \mathrm{~h}$ & 6.96 \\
Water & Kept in water-bath at $100^{\circ} \mathrm{C}$ for 40 minutes & 8.37 \\
Water & Autoclave for 40 minutes & 19.15 \\
$0.04 \% \mathrm{NaOH}$ solution & Kept in water-bath at $100{ }^{\circ} \mathrm{C}$ for 40 minutes & 16.14 \\
$2 \% \mathrm{Na}_{2} \mathrm{SO}_{3}$ solution & Autoclave for 40 minutes & 20.12 \\
$4 \% \mathrm{Na}_{2} \mathrm{SO}_{3}$ solution & Autoclave for 40 minutes & 26.83 \\
$6 \% \mathrm{Na}_{2} \mathrm{SO}_{3}$ solution & Autoclave for 40 minutes & 31.20 \\
$50 \%$ methanol & Kept at room temperature for $24 \mathrm{~h}$ & 16.06 \\
$50 \%$ methanol & Reflux for 4 hours & 20.02 \\
$50 \%$ methanol $+\mathrm{Na}_{2} \mathrm{SO}_{3} 2 \%$ & Reflux for 4 hours & 24.91 \\
$50 \%$ acetone & Kept at room temperature for $24 \mathrm{~h}$ & 17.45 \\
$50 \%$ acetone & Reflux for 4 hours & 22.28 \\
$50 \%$ acetone $+\mathrm{Na}_{2} \mathrm{SO}_{3} 2 \%$ & Reflux for 4 hours & 27.17 \\
\hline
\end{tabular}

or distilled water was $5 \%-12 \%$, depending on the duration time of soaking. The longer the time of soaking or agitation, the higher yield of extract was. In this experiment, the duration of soaking was shortened when the temperature was raised. The higher the temperature of extraction, especially when it was combined with pressure, the higher the yield of tannin (19.15\%).

Addition of sodium sulphite to water increased the yield of tannin. Similar increase was also found (20\%$25 \%$ higher) when sodium sulphite was added to $50 \%$ methanol or $50 \%$ acetone (Table 2). The yield of tannin increased with the increasing concentration of sodium sulphite in the solution. This was shown in this experiment where the yield of tannin extracted by $6 \%$ sodium sulphite solution was the highest $(31.20 \%)$. The result in agreement with Hoong et al. (2009) who reported that addition of sodium sulphite in water increased tannin extract from $15 \%$ to $25 \%$ from Acacia mangium bark. This is due to the reaction between sodium sulphite and the phenolic hydroxyl group of tannin to form a sulfonated polyflavonoid (Herrick, 1980). Although the yield was high, this new form of tannin has not been tested for its biological property in the rumen fermentation.

Aqueous methanol or acetone gave a higher yield compared to water extraction. Previously, Susana et al. (1994) also reported that higher yield of tannin from leguminous forages was obtained when extracted with aquoeus methanol or acetone. The yield was almost similar to those extracted by sodium sulphite solution. Because of the high price of the solvent, none of the

Table 3. Tannin content in the extractive fraction extracted by different solution and methods from Acacia mangium bark

\begin{tabular}{|c|c|c|c|c|}
\hline \multirow[t]{2}{*}{ Solution } & \multirow[t]{2}{*}{ Method of extraction } & Total phenol & Total tannin & $\begin{array}{c}\text { Condensed } \\
\text { tannin }\end{array}$ \\
\hline & & \multicolumn{3}{|c|}{ (\% bark weight) } \\
\hline Water & Kept at room temperature for $24 \mathrm{~h}$ & 7.14 & 4.47 & 1.20 \\
\hline Water & Kept in water-bath at $100^{\circ} \mathrm{C}$ for 40 minutes & 15.29 & n.a. & 2.52 \\
\hline Water & Autoclave for 40 minutes & 14.16 & n.a. & 2.48 \\
\hline $0.04 \% \mathrm{NaOH}$ solution & Kept in water-bath at $100^{\circ} \mathrm{C}$ for 40 minutes & 16.74 & n.a. & 2.85 \\
\hline $2 \% \mathrm{Na}_{2} \mathrm{SO}_{3}$ solution & Autoclave for 40 minutes & 11.29 & 7.87 & 3.65 \\
\hline $4 \% \mathrm{Na}_{2} \mathrm{SO}_{3}$ solution & Autoclave for 40 minutes & 13.26 & 8.41 & n.a. \\
\hline $6 \% \mathrm{Na}_{2} \mathrm{SO}_{3}$ solution & Autoclave for 40 minutes & 24.91 & 18.26 & n.a. \\
\hline $50 \%$ methanol & Kept at room temperature for $24 \mathrm{~h}$ & 8.05 & n.a. & 3.15 \\
\hline $50 \%$ methanol & Reflux for 4 hours & 16.22 & 10.47 & 2.79 \\
\hline $50 \%$ methanol $+\mathrm{Na}_{2} \mathrm{SO}_{3} 2 \%$ & Reflux for 4 hours & 19.53 & 11.28 & 2.39 \\
\hline $50 \%$ acetone & Kept at room temperature for $24 \mathrm{~h}$ & 11.83 & n.a. & 3.49 \\
\hline $50 \%$ acetone & Reflux for 4 hours & 22.49 & 12.98 & 3.44 \\
\hline $50 \%$ acetone $+\mathrm{Na}_{2} \mathrm{SO}_{3} 2 \%$ & Reflux for 4 hours & 26.52 & 16.47 & 3.46 \\
\hline
\end{tabular}

Note: n.a.= not any 
solvent used for tannin extraction was carried out on a commercial scale (Herrick, 1980). According to Li \& Maplesden (1998), only water extraction with or without addition of chemicals (sulphite or sodium hydroxide) is relatively economically feasible. However, this water extraction should be carried out at high temperature and pressure (Duan et al., 2005).

\section{Tannin Content in the Extract}

Tannin content in different extracts is described as total phenol, total tannin and condensed tannin (Table 3). The highest total phenol or total tannin content was found in the fraction extracted by a mixture of $50 \%$ acetone and $2 \%$ sodium sulphite $(26.52 \%)$.

Addition of $6 \%$ sodium sulphite to water increased total phenol or total tannin contents of the extract. It means that the addition of sodium sulphite resulted in higher yield of the extract and higher content of total tannin or condensed tannin compared to other solvent without sodium sulphite. Although higher temperature increased total phenol or total tannin content, it did not increase condensed tannin content. This may be due to the solubility of condensed tannin in the solution did not increase even the temperature of extraction was raised or some of condensed tannins might be destroyed during heating.

\section{Biological Property of Tannin}

Makkar (2003) developed a method to evaluate the effect of secondary compounds especially tannin on the

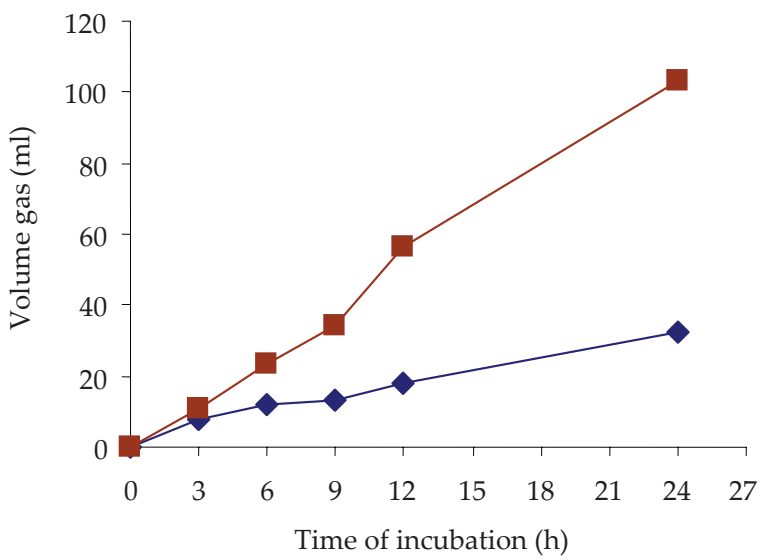

Figure 1. Effect of tannin extract with (-m-) and without (polyethylene glycol on gas production $(\mathrm{ml})$ during in vitro rumen fermentation of milled soybean meal

in vitro rumen fermentation. Tannin has a property to bind any protein and make this protein undigested by proteolytic enzyme in the rumen. Tannin in the rumen also causes lower gas production, and when the binding is very strong, this tannin-protein complex will not be degraded along the digestive tract and come out with faeces (Jayanegara \& Sofyan, 2008).

When PEG was added to tannin in the in vitro system, the gas production increased significantly (Figure 1) since tannin will bind preferably to PEG than protein. Therefore, the protein or substrate will be degraded

Table 4. Biological property of tannin extracted by different solutions and methods from Acacia mangium bark described as percentage of gas increase

\begin{tabular}{|c|c|c|c|}
\hline Solution & Method of extraction & $\begin{array}{c}\text { Volume gas } \\
\text { production }(\mathrm{ml})\end{array}$ & Gas increase (\%) \\
\hline Water (5mg/ml buffer) & autoclave & 44.58 & \\
\hline Water + PEG & & 95.69 & 114.66 \\
\hline $2 \% \mathrm{Na}_{2} \mathrm{SO}_{3}$ solution $(5 \mathrm{mg} / \mathrm{ml}$ buffer $)$ & autoclave & 67.64 & \\
\hline $2 \% \mathrm{Na}_{2} \mathrm{SO}_{3}$ solution $+\mathrm{PEG}$ & & 98.95 & 46.29 \\
\hline $4 \% \mathrm{Na}_{2} \mathrm{SO}_{3}$ solution $(5 \mathrm{mg} / \mathrm{ml}$ buffer $)$ & autoclave & 14.67 & \\
\hline $4 \% \mathrm{Na}_{2} \mathrm{SO}_{3}$ solution + PEG & & 14.77 & 0.68 \\
\hline $6 \% \mathrm{Na}_{2} \mathrm{SO}_{3}$ solution $(5 \mathrm{mg} / \mathrm{ml}$ buffer $)$ & autoclave & 3.72 & \\
\hline $6 \% \mathrm{Na}_{2} \mathrm{SO}_{3}$ solution + PEG & & 3.82 & 2.70 \\
\hline $50 \%$ methanol (5 mg/ml buffer) & reflux & 47.39 & \\
\hline $50 \%$ methanol + PEG & & 91.82 & 93.74 \\
\hline $50 \%$ methanol $+\mathrm{Na}_{2} \mathrm{SO}_{3} 2 \%(5 \mathrm{mg} / \mathrm{ml}$ buffer $)$ & reflux & 44.58 & \\
\hline $50 \%$ methanol $+\mathrm{Na}_{2} \mathrm{SO}_{3} 2 \%+\mathrm{PEG}$ & & 101.77 & 128.30 \\
\hline $50 \%$ acetone $(5 \mathrm{mg} / \mathrm{ml}$ buffer $)$ & reflux & 32.67 & \\
\hline $50 \%$ acetone + PEG & & 103.32 & 216.31 \\
\hline $50 \%$ acetone $+\mathrm{Na}_{2} \mathrm{SO}_{3} 2 \%(5 \mathrm{mg} / \mathrm{ml}$ buffer $)$ & reflux & 36.03 & \\
\hline $50 \%$ acetone $+\mathrm{Na}_{2} \mathrm{SO}_{3} 2 \%+\mathrm{PEG}$ & & 91.87 & 154.95 \\
\hline Powder tannin isolate $(1.25 \mathrm{mg} / \mathrm{ml}$ buffer $)$ & & 58.80 & \\
\hline Powder tannin isolate + PEG & & 112.87 & 91.97 \\
\hline
\end{tabular}


faster and produced higher gas production. The difference of gas produced after 24 hours of fermentation in the presence or without PEG is expressed as the biological property of tannin. The higher percentage of gas increased due to PEG addition, the higher the adverse effect of tannin extract (Jayanegara et al., 2009).

Table 4 shows that the percentage increase in gas production varied from $0.68 \%$ to $216.31 \%$. The addition of sodium sulfite to either water or $50 \%$ acetone reduced the percentage increase in gas production and the higher the inclusion of sodium sulfite $(4 \%$ or $6 \%)$, the bigger the reduction. When tannin that was extracted with solution containing $2-6 \%$ of sodium sulfite was added to the in vitro fermentation bottle, the concentration of sodium sulfite in each bottle ranged from $2-6 \mathrm{mg} / \mathrm{ml}$ of rumen buffer.

This concentration was too high and may be toxic to rumen microbes, hence, negatively affected rumen fermentation. Sodium sulphite at lower concentration (0.75 $\mathrm{mg} / \mathrm{ml}-1.0 \mathrm{mg} / \mathrm{ml}$ ), however, was reported to be beneficial for rumen microbes. It decreased molar percentage of acetate and increased that of propionate and butyrate and also reduced methane production in the rumen of dairy cows (Bal \& Ozturk, 2006). Eventhough, it shows that sodium sulfite increased yield of tannin and did not change tannin's property to make formaldehyde-tannin resin (Hoong et al., 2009), this compound should be used at low concentration to extract tannin especially if this tannin will be used as feed additive in ruminant diet.

The highest percentage of increase in gas production $(216.31 \%)$ was found when tannin extracted by $50 \%$ acetone was added into the fermentation, meaning that the highest biological activity was shown by tannin that was extracted with $50 \%$ acetone. Tannin extracted with water or $50 \%$ methanol had lower biological activity than that of $50 \%$ acetone. Tannin extracted by $50 \%$ acetone would cause adverse effect when it was used at high level in the ruminant feed as it would reduce protein availability for ruminant. The level of tannin extract to give a beneficial effect may vary depending on type of tannin extract or diet composition. However, Frutos et al. (2004) reported that the maximum level of tannin in the diet that reduced protein degradation in the rumen and increased amino acid flow to the intestine was $4 \%$.

\section{CONCLUSION}

Although it gave higher yield of extract, the addition of sodium sulphite is not recommended to extract tannin if the tannin will be used as feed additive for ruminant. The aqueous acetone (50\% acetone) solution is a better choice to be used as it gave a high yield of tannin extract which showed the highest biological activity (\% increase gas $=216 \%$ ). The optimum level of tannin extract added to the diet should be further evaluated to give the beneficial effect of tannin on protein protection and increase amino acid flow.

\section{ACKNOWLEDGEMENT}

This work has been funded by APBN G-4/RK/NUT/ APBN/06, Balai Penelitian Ternak. Thank you to Sintha Utaminingsih and Eka Susilawati for their help in this work.

\section{REFERENCES}

Bal, M. A. \& D. Ozturk. 2006. Effects of sulfur containing supplements on ruminal fermentation and microbial srotein Synthesis. Res. J. Anim. and Vet. Sci. 1: 33-36.

Cenci, F. B., H. Louvandini, C. M. McManus, A. Dellporto, D. M. Costa, S. C. Araujo, A. P. Minho, \& A. L. Abdalla. 2007. Effects of condensed tannin from Acacia mearnsii on sheep infected naturally with gastrointestinal helminthes Vet. Parasitol. 144: 132-137.

Duan, W., S. Ohara, K. Hasida, \& R. Makino. 2005. Condensed tannins from steamed Acacia mearnsii bark. Holzforschung 59: 289-294.

Frutos, P., G. Hervás, F. J. Giráldez, \& A. R. Mantecón. 2004. Review. Tannins and ruminant nutrition. Spanish J. Agric. Res. 2:191-202

Herrick, F. W. 1980. Chemistry and utilization of Western Hemlock bark extractives. J. Agric. Food Chem. 28: 228-237.

Hoong, Y. B., M. T. Paridah, C. A. Luqman, M. P. Koh, \& Y. F. Loh. 2009. Fortification of sulfited tannin from the bark of Acacia mangium with phenol-formaldehyde for use as plywood adhesive. Industrial Crops and Products, 30 (3): 416-421

Jayanegara, A \& A. Sofyan. 2008. Penentuan aktivitas biologis tanin beberapa hijauan secara in vitro menggunakan "hohenheim gas test" dengan polietilen glikol sebagai determinan. Med. Pet. 31: 44-52.

Jayanegara, A., A. Sofyan, H. P. S Makkar, \& K. Becker. 2009. Gas production kinetics, organic matter digestibility and methane production in vitro in hay and straw diets supplemented by tannin-containing forages. Med. Pet. 32: 120-129.

Krisper, P., V. Tisler, V. Skubic, I. Rupnik, \& S. Kobal. 1992. The use of tannin from chestnut (Castanea vesca). Basic Life Sci. 59:1013-1019.

Li, J. \& F. Maplesden. 1998. Commercial production of tannin from radiata pine bark for wood adhesives. IPENZ Transactions 25: 46-52.

Makkar, H. P. S. 2003. Quantification of tannin in tree and shrub foliage. A laboratory manual. Kluwer Academic Publishers, Netherlands.

Min, B. R., T. N. Barry, G. T. Attwood, \& W. C. McNabb. 2003. The effect of condensed tannin on the nutrition and health of ruminants fed fresh temperate forages: A review. Anim. Feed Sci. Tech 106: 3-19.

Ofinade, K. R. 1997. The production of tannin from the bark of Eucalyptus camadulensis. http://www.journal.au.edu/ au_techno/2001/oct2001/article2.pdf, 13 Maret 2007

Palma, G. J. Freer \& J. Baeza. 2003. Removal of metal ions by modified Pinus radiata bark and tannins from water solutions.Water Res. 37: 4974-4980.

Susana, I. W. R., E. Wina, \& B. Tangendjaja. 1994. Ekstraksi tanin kaliandra dengan berbagai bahan pengekstrak dan interaksinya dengan berbagai protein dan kondisi $\mathrm{pH}$. Ilmu dan Peternakan 8: 38-42. 